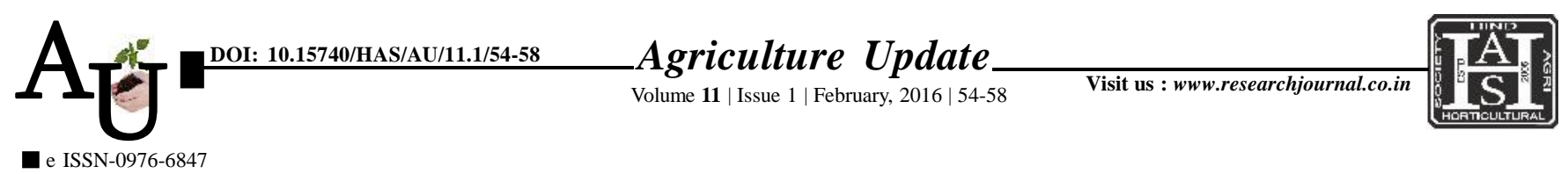

\title{
Research Article: Constraints faced by elected women village Panchayat members in role performance
}

\author{
ANURADHA RANJAN KUMARI AND LAXMIKANT
}

Article Chronicle: Received :

28.11.2015;

Revised :

06.01.2016;

Accepted :

20.01.2016

\section{KeY Words :}

Constraints, Elected

women village

Panchayat members,

Panchayati Raj

Institutions
Author for correspondence :

\section{ANURADHA RANJAN} KUMARI

Krishi Vigyan Kendra (ICAR-IIVR), Malhana, DEORIA (U.P.) INDIA Email: anuradha_rau@ rediffmail.com

See end of the article for authors' affiliations
SUMMARY : Women have been an integral part of social structure not only because their importance in the perpetuation of human race but also by virtue of their significant contribution in socio-economic progress. Despite this, time and again they have been subjected to discrimination due to gender bias and have been denied equality of status and opportunities in social economic and political spheres of life. The present study was an effort to know the profile of elected women village Panchayat members and constraints faced by elected women Panchayat members in role performance. Total seventy five women representatives randomly selected from Pusa and Kalyanpur block of Samastipur district in Bihar. The study reveals that majority of the women members of the Gram Panchayat were within 35 years of age (73.33\%), 46.66 per cent of respondents were from forward caste, a large majority $(98.66 \%$ and $97.33 \%$ ) of EWVPMs were married and were housewives only, respectively, personally possessed low (up to $8^{\text {th }}$ standard) level of education $(48.0 \%)$ and also had high family education (29.33\%). They by and large enjoyed a nuclear family (64.00\%) but the majority had 3-5 members $(42.66 \%)$, these respondents owned land up to 2.5 acre (58.66\%) and lived with low material possession (84.0\%). The family income of more than half of the members $(64.0 \%)$ of respondents had low income group below 20,000 annually, having as many as $(42.66 \%)$ of the members had mixed house $(76.0 \%)$ of respondents had not membership of any social institution. Out of 11 constraints of role performance by EWVPMs, 8 viewed as most serious were lack of resources for development work $(90.66 \%)$, lack of fund on time for carrying out the work of the projects $(88.00 \%)$, lack of knowledge to the members (82.66\%), nonavailability of persons well versed with the rural projects $(80.0 \%)$, lack of interest in Mukhiya for developmental works $(80.0 \%)$, carelessness among villagers for development works $(74.66 \%)$ lack of education among Panchayat members $(69.33 \%)$ and bribery and misappropriation of funds $(54.66 \%)$. The maximum number of EWVPMs considered economical constraints to be acting as the greatest hindrance in the way of their role performance (93.33\%).

How to cite this article : Kumari, Anuradha Ranjan and Laxmikant (2016). Constraints faced by elected women village Panchayat members in role performance. Agric. Update, 11(1): 54-58. 